\title{
SISTEM PENGINGAT PADA GUDANG PT. ALFA BEAUTY COSMETICA MENGGUNAKAN SMS GATEWAY
}

\author{
Arey Nur Warisman ${ }^{1}$, Umniy Salamah ${ }^{2}$, Yuwan Jumaryadi ${ }^{3}$ \\ ${ }^{1,2,3}$ Fakultas Ilmu Komputer \\ Universitas Mercu Buana \\ ${ }^{2}$ umniy.salamah@mercubuana.ac.id, ${ }^{3}$ yuwan.jumaryadi@mercubuana.ac.id
}

\begin{abstract}
The development of technology is very important for humans, especially in the field of storage of goods that become a useful and important thing in the world of warehousing. In this study the authors take a case study at PT. Alfa Beauty Cosmetica who still uses warehouse reports manually. This study aims to facilitate the work of employees of PT. Alfa Beauty Cosmetica. Employees can store in-app items consisting of goods unique code, item name, recording location of goods and recording transactions of goods. Message reminder simulation is if stock will run out using web based Gateway SMS. With stock reminder messages, employees are quicker at updating inventory. This application is expected to accelerate employee work.
\end{abstract}

Keywords: SMS Gateway, PT. Alfa Beauty Cosmetica, Stock Items, Reminder Messages, Warehousing

\begin{abstract}
ABSTRAK
Perkembangan teknologi merupakan hal yang sangat penting bagi manusia, terutama dibidang penyimpanan barang yang menjadi suatu hal yang berguna dan penting dalam dunia pergudangan. Pada penelitian kali ini penulis mengambil studi kasus pada PT. Alfa Beauty Cosmetica yang masih menggunakan laporan gudang secara manual. Penelitian ini bertujuan untuk mempermudah pekerjaan karyawan PT. Alfa Beauty Cosmetica. Karyawan dapat menyimpan barang dalam aplikasi yang terdiri dari kode unik barang, nama barang, mencatat lokasi barang dan mencatat transaksi barang. Simulasi pengingat pesan yaitu jika stok akan habis menggunakan SMS Gateway berbasis web. Dengan adanya pesan pengingat stok, karyawan lebih cepat dalam memperbarui stok barang. Aplikasi ini diharapkan dapat mempercepat pekerjaan karyawan.
\end{abstract}

Kata Kunci: SMS Gateway, PT. Alfa Beauty Cosmetica, Stok Barang, Pesan Pengingat, Pergudangan 


\section{PENDAHULUAN}

Teknologi berkembang dengan cepat saat ini, dan perkembangan teknologi dapat membuat beberapa aspek dalam kehidupan menjadi lebih efisien [1]. Perkembangan teknologi dalam bidang pergudangan merupakan hal yang sangat penting [2]. Gudang adalah salah satu tempat dimana bahan baku atau barang sudah jadi disimpan dengan rapih sehingga pemilik gudang mudah untuk mengetahui letak ataupun jumlah sebuah barang. Untuk penyimpanan barang yang baik, diperlukannya teknologi yang mendukung. Ditambah dengan daya konsumsi yang terus meningkat pada zaman sekarang. Sehingga teknologi dapat dimanfaatkan untuk mempermudah suatu pekerjaan.

Perkembangan di bidang teknologi informasi sangat pesat, web yang dinamis merupakan sarana yang cukup mudah untuk membantu pekerjaan. Adanya keinginan untuk mengoptimalkan fungsi dari web aplikasi untuk pergudangan dengan cara menggunakan teknologi pengingat pesan, yaitu teknologi dengan konsep yang menggabungkan web aplikasi dan teknologi pengingat pesan. Pada PT. Alfa Beauty Cosmetica pencatatan barang masih menggunakan kertas sehingga pelaporan jumlah barang terhambat. Pembuatan aplikasi ini adalah untuk membangun aplikasi berbasis Web yang memudahkan karyawan untuk mengatasi permasalahan penyimpanan barang yang berada di gudang PT. Alfa Beauty Cosmetica.

Dari permasalahan yang ada pada PT. Alfa Beauty Cosmetica maka pembuatan aplikasi ini adalah untuk membangun aplikasi berbasis Web yang menggunakan teknologi PHP, MySQL, dan juga GAMMU yang memudahkan karyawan untuk mengatasi permasalahan penyimpanan barang yang berada di gudang PT. Alfa Beauty Cosmetica.

\section{METODOLOGI}

\subsection{Metodologi Pengembangan Perangkat Lunak}

Metodologi pengembangan perangkat lunak yang digunakan dalam penelitian ini yaitu SDLC Waterfall. Tahapan-tahapannya yaitu [3]:

1. Analysis. Tahapan ini merupakan tahapan dimana System Engineering melakukan analisis terhadap hal-hal yang berkaitan dengan pengembangan perangkat lunak. Langkah ini bertujuan untuk memahami sistem yang ada, dan mengidentifikasi permasalahan yang terjadi, serta mencari solusi terhadap permasalahan tersebut. Menganalisa masalah dimulai dengan mengkaji subjek permasalahan yang ada. Permasalahan yang ada di PT Alfa Beauty Cosmetica adalah data stok barang pada PT yang banyak tidak diketahui jumlah stok masuk dan stok keluar. Masalah ini disebabkan karena stok barang yang masuk dan keluar masih ditulis secara manual yaitu menggunakan alat tulis pulpen dan kertas sehingga ketika kertas catatan hilang tidak tercadangkan dengan baik. Dan tidak ketahuinya jumlah stok barang yang menipis, sehingga tim pergudangan sulit untuk menyetok ulang barang yang menipis. Dari permasalahan tersebut penulis mengidentifikasi penyebabnya yaitu belum adanya sistem perekaman stok barang masuk maupun keluar, pengingat sisa stok barang.

2. Design. Pada tahapan ini dilakukan penerjemahan terhadap kebutuhan yang diperlukan terhadap data yang telah dianalisis ke dalam bentuk yang mudah dimengerti untuk tahap selanjutnya.

3. Coding. Tahapan ini merupakan tahap dimana dilakukan pengimplementasian atas perancangan yang telah dibuat ke dalam Bahasa pemrograman yang dipilih. Bahasa Pemrograman yang akan digunakan yaitu PHP, dan Database yang akan digunakan yaitu MySQL serta menggunakan aplikasi GAMMU.

4. Testing. Tahapan ini merupakan tahapan uji coba terhadap sistem atau program yang telah selesai dibuat. Apabila masih terdapat bugs pada sistem yang dibuat maka bugs tersebut akan diperbaiki.

5. Maintenance. Tahapan ini merupakan tahapan akhir dari pengembangan perangkan lunak, dimana pada tahapan ini sistem yang dibuat telah diterapkan dan disertai pemeliharaan jika adanya perubahan requirement.

\subsection{Metodologi Pengambilan Data}

Metode pengumpulan data yang dilakukan dalam penelitian ini adalah:

1. Observasi

Pengumpulan data dengan melakukan pengamatan secara langsung terhadap objek 
penelitian, dengan mencatat hal-hal penting yang berhubungan dengan judul laporan, sehingga diperoleh data yang lengkap dan akurat.

\section{Studi Pustaka}

Pengumpulan data dengan menggunakan atau mengumpulkan sumber-sumber tertulis, dengan cara membaca, mempelajari dan mencatat halhal penting yang berhubungan dengan masalah yang sedang dibahas guna memperoleh gambaran secara teoritis.

3. Metode Wawancara

Menggunakan metode wawancara juga dilakukan untuk mendapatkan informasi dengan cara bertanya langsung proses bisnis untuk pengembangan aplikasi.

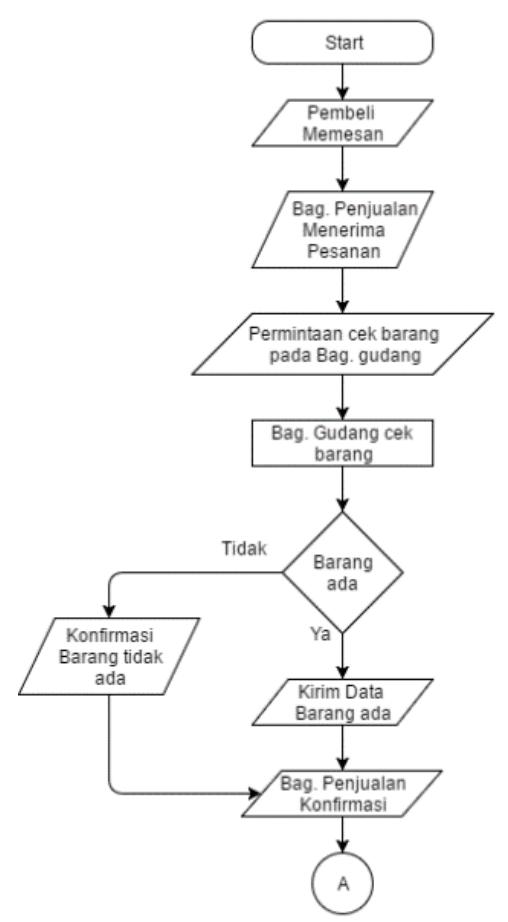

\subsection{Metodologi Pengujian Perangkat Lunak}

Metode Black-box merupakan metode pengujian perangkat lunak yang digunakan. Metode ini berfokus pada tujuan fungsi aplikasi, serta tujuan fungsionalitas yang ada dalam aplikasi [3]. Pengujian yang akan diujikan meliputi, login, menambah user, mengubah user, menghapus user, menambah barang, mengubah barang, menghapus barang dan melihat laporan.

\section{HASIL DAN PEMBAHASAN}

\subsection{Analisis Sistem Berjalan}

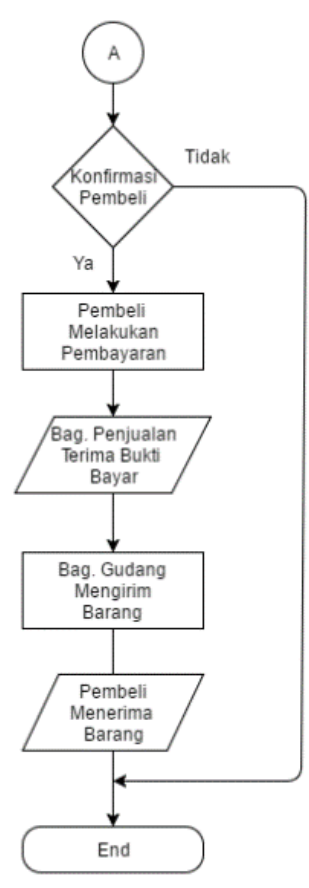

Gambar 1. Flowchart sistem berjalan

Penjelasan tahapan flowchart (Gambar 1) adalah sebagai berikut:

1. Hal pertama yaitu pembeli memesan barang.

2. Bagian penjualan menerima pesanan tersebut untuk diproses

3. Proses pengecekan barang dilakukan oleh bagian gudang yang terlebih dahulu menerima perintah dari bagian penjualan

4. Bagian penjualan membuat permintaan ke bagian gudang untuk melakukan pengecekan barang

5. Proses pengecekan barang oleh bagian gudang
6. Jika barang ada maka bagian gudang akan mengirim data ke bagian penjualan, sedangkan bila tidak ada maka bagian gudang kemudian menginformasikan kepada bagian penjualan bahwa barang yang dipesan tidak tersedia.

7. Bagian penjualan mengkonfirmasi pelanggan terkait ada atau tidaknya barang pada gudang, jika barang ada maka lanjut ke proses pembayaran pembeli. Jika barang tidak ada, maka transaksi selesai.

8. Pembeli melakukan proses pembayaran.

9. Bagian penjualan menerima laporan bahwa pembeli telah membayar 
10. Bagian gudang melakukan proses pengiriman barang sesuai permintaan bagian penjualan.

11. Pembeli menerima barang yang telah di pesan.

\subsection{Perancangan Sistem}

a. Use Case Diagram

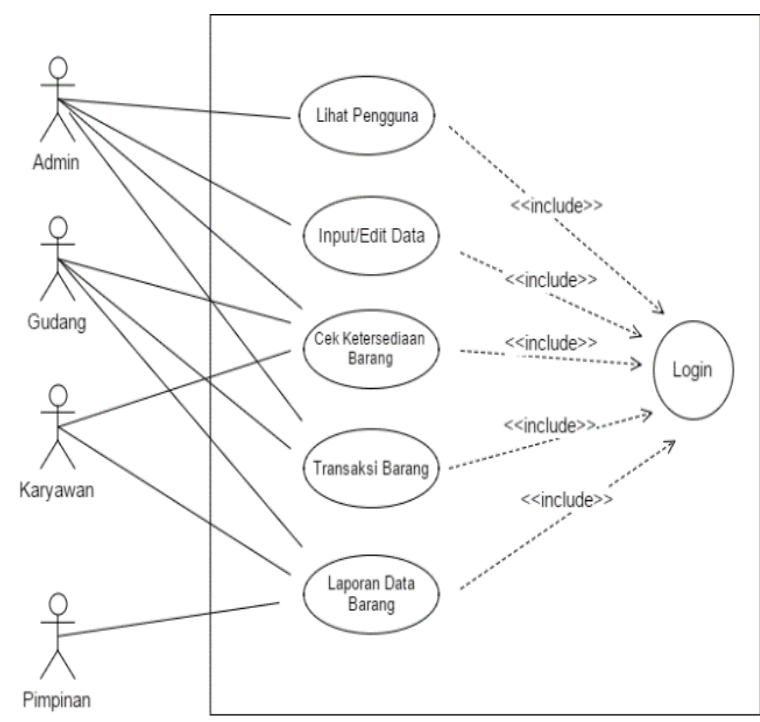

Gambar 2. Use case diagram sistem pengingat pada gudang

Dapat diketahui dari Gambar 2 bahwa sistem pengingat pada gudang terdiri dari 4 aktor, yaitu Admin, Gudang, Karyawan, dan Pimpinan. Admin dapat melakukan aktivitas melihat pengguna, melakukan input atau edit data, memeriksa ketersediaan barang, dan melakukan transaksi terhadap barang, sedangkan gudang dapat melakukan aktivitas memeriksa ketersediaan barang, melakukan transaksi terhadap barang, dan melihat laporan data barang. Karyawan dapat memeriksa ketersediaan barang, dan melihat laporan data barang, sedangkan pimpinan hanya dapat melihat laporan data barang. Semua aktivitas tersebut hanya dapat dilakukan dengan melakukan login terlebih dahulu.

Tabel 1. Use case diagram login.

\begin{tabular}{cc}
\hline $\begin{array}{c}\text { Nama Use } \\
\text { Case }\end{array}$ & Login \\
\hline Aktor & $\begin{array}{c}\text { Admin, Karyawan, Gudang, } \\
\text { Pimpinan }\end{array}$ \\
\hline Deskripsi & $\begin{array}{c}\text { Sistem melakukan verifikasi } \\
\text { pengguna, dimana jika super } \\
\text { admin, maka aplikasi akan }\end{array}$ \\
\hline
\end{tabular}

menampilkan beberapa fitur yang dapat diakses jika user memiliki tingkatan pengguna khusus

Tabel 2. Use case diagram lihat data pengguna.

\begin{tabular}{cc}
\hline $\begin{array}{c}\text { Nama Use } \\
\text { Case }\end{array}$ & Lihat Data Pengguna \\
\hline Aktor & Admin \\
\hline $\begin{array}{c}\text { Deskripsi } \\
\text { Singkat }\end{array}$ & $\begin{array}{c}\text { Admin melakukan proses } \\
\text { pengisian, edit, hapus data } \\
\text { pengguna perusahaan dan } \\
\end{array}$ \\
& mengatur hak akses pengguna. \\
\hline
\end{tabular}

Tabel 3. Use case diagram input data barang.

\begin{tabular}{cc}
\hline $\begin{array}{c}\text { Nama Use } \\
\text { Case }\end{array}$ & Input Data Barang \\
\hline Aktor & Admin, Karyawan dan Gudang \\
\hline Deskripsi & Pengguna masuk ke activity \\
Singkat & input/edit data barang, dimana \\
& dalam activity tersebut pengguna \\
& dapat menginput data barang \\
& yang berada di perusahaan. \\
& Kemudian pengguna diharuskan \\
& untuk mengisi detail data untuk \\
& melengkapi proses data. \\
\hline
\end{tabular}

Tabel 4. Use case diagram cek ketersediaan barang.

\begin{tabular}{cc}
\hline $\begin{array}{c}\text { Nama Use } \\
\text { Case }\end{array}$ & Cek Ketersediaan Barang \\
\hline Aktor & Admin, Gudang dan Pimpinan \\
\hline Deskripsi & Pengguna masuk ke activity \\
Singkat & laporan ketersediaan barang, \\
& dimana dalam activity pengguna \\
& dapat melihat semua data \\
& barang. Kemudian pengguna \\
dapat melihat detail data barang \\
\end{tabular}

Tabel 5. Use case diagram transaksi barang.

\begin{tabular}{cc}
\hline $\begin{array}{c}\text { Nama Use } \\
\text { Case }\end{array}$ & Cek Ketersediaan Barang \\
\hline Aktor & Admin dan Gudang \\
\hline Deskripsi & Pengguna masuk ke activity \\
Singkat & transaksi barang, dimana dalam \\
& activity pengguna dapat \\
& mengurang dan menambah stok \\
& barang. Kemudian pengguna \\
& menerima SMS secara otomatis \\
& ketika stok barang berkurang. \\
\hline
\end{tabular}


Tabel 6. Use Case diagram laporan barang.

\begin{tabular}{cc}
\hline $\begin{array}{c}\text { Nama Use } \\
\text { Case }\end{array}$ & Buat Laporan \\
\hline Aktor & Karyawan dan Pimpinan \\
\hline Deskripsi & Karyawan membuat laporan \\
Singkat & guna diserahkan kepada \\
& pimpinan. \\
\hline
\end{tabular}

\section{b. Activity Diagram}

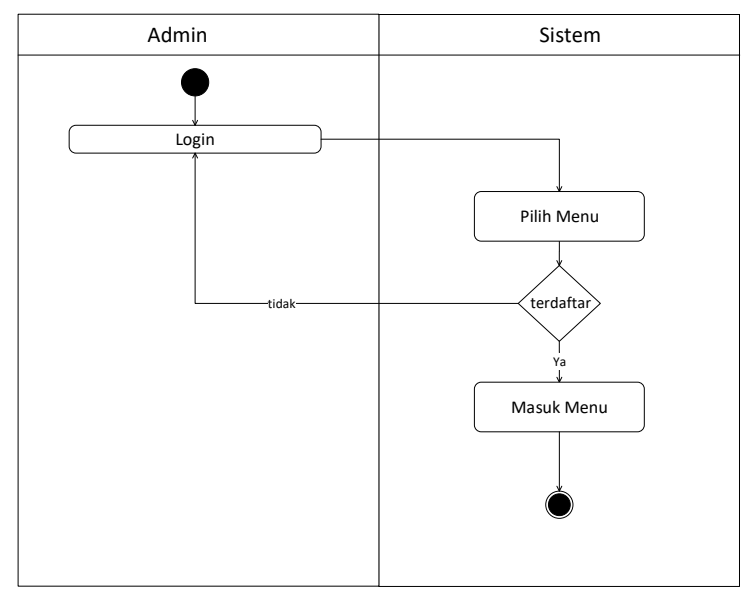

Gambar 3. Activity login

Dapat diketahui dari Gambar 3 bahwa user melakukan login dengan menginputkan username dan password. Jika username dan password sesuai dengan yang ada di database maka akan masuk ke menu, jika username dan password tidak sesuai dengan database maka sistem akan menampilkan "Login Gagal" dan kembali ke halaman awal login.

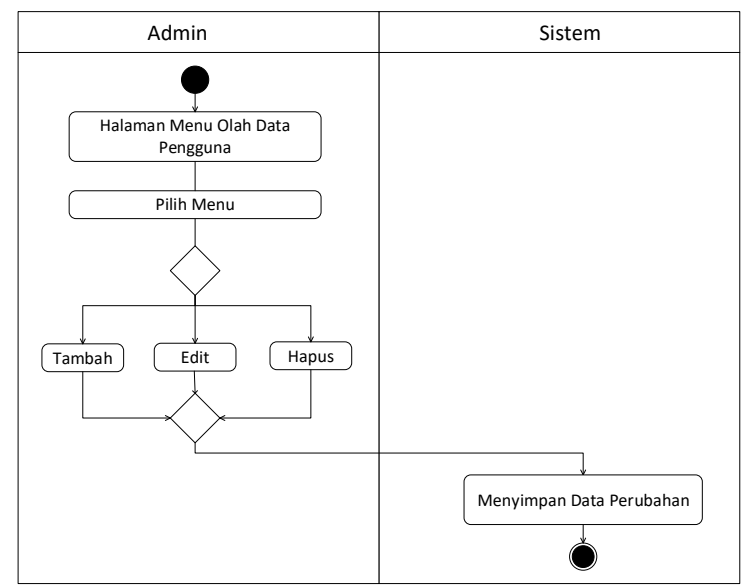

Gambar 4. Activity input data pengguna

Admin masuk ke menu pengguna. Admin dapat menambah pengguna, edit data pengguna dan menghapus data pengguna (Gambar 4).

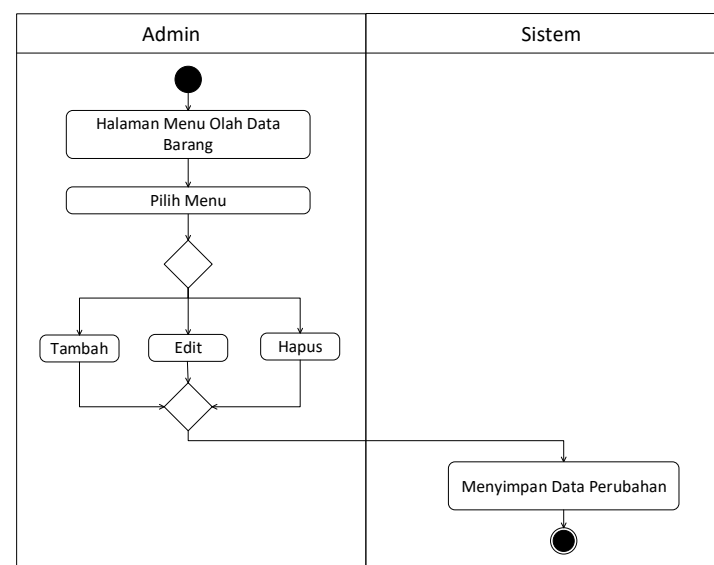

Gambar 5. Gambar activity input barang

User masuk ke menu pengguna. User dapat menambah barang, edit data barang dan menghapus data barang (Gambar 5).

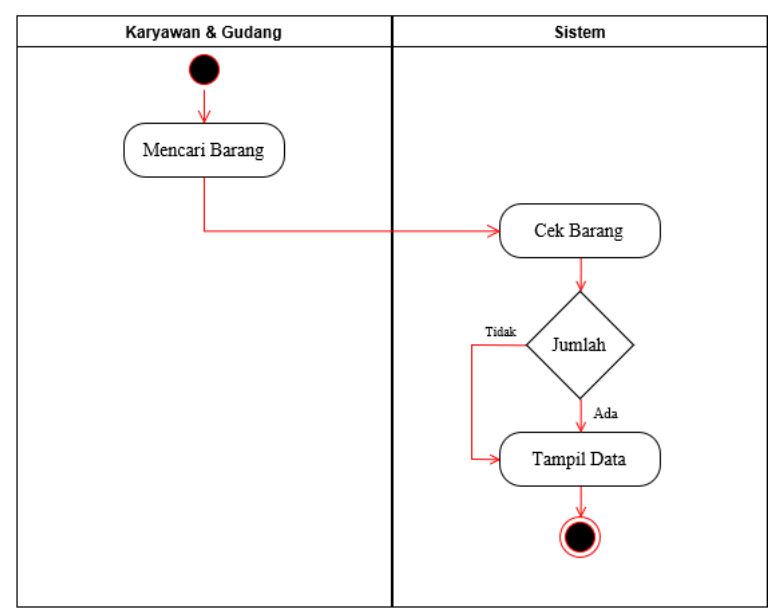

Gambar 6. Gambar activity diagram cek barang

Dapat diketahui dari Gambar 6 bahwa ada proses:

1. Karyawan dan Pegawai mencari barang dengan mengetikkan inisial dari barang

2. Sistem akan mengecek barang-barang sesuai inisial barang yang diminta oleh user

3. Jika jumlah ada maka detail barang tampil di layar, jika jumlah tidak ada maka detail barang tampil berikut pesan peringatan untuk user agar menambah stok barang. 


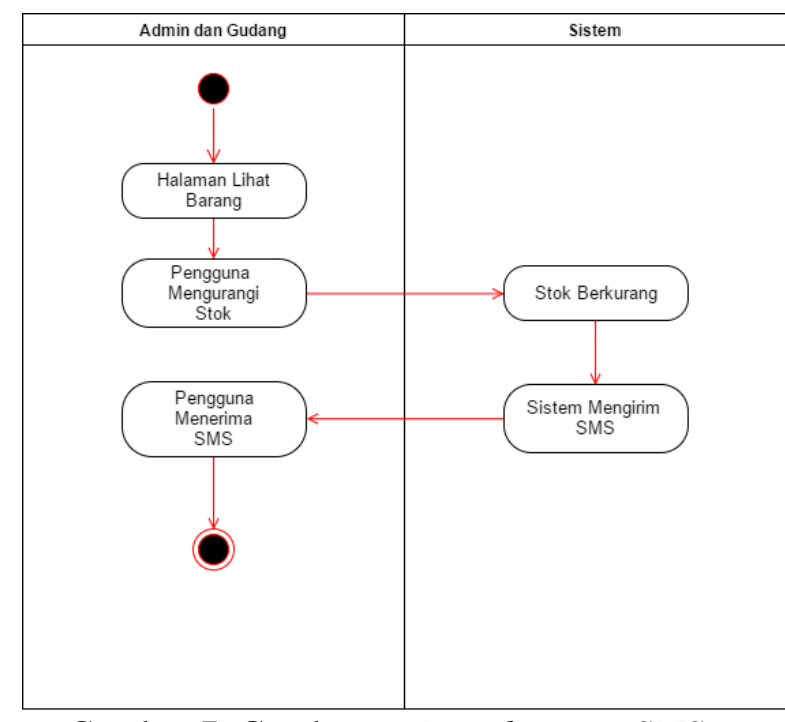

Gambar 7. Gambar activity diagram SMS

Dapat diketahui dari Gambar 7 bahwa:

1. User memasuki halaman lihat barang

2. User mengurangi stok barang

3. Stok berkurang pada satu halaman, yaitu halaman lihat barang

4. Sistem secara otomatis mengirim SMS pengingat kepada nomor telepon yang dituju

5. Pengguna menerima SMS

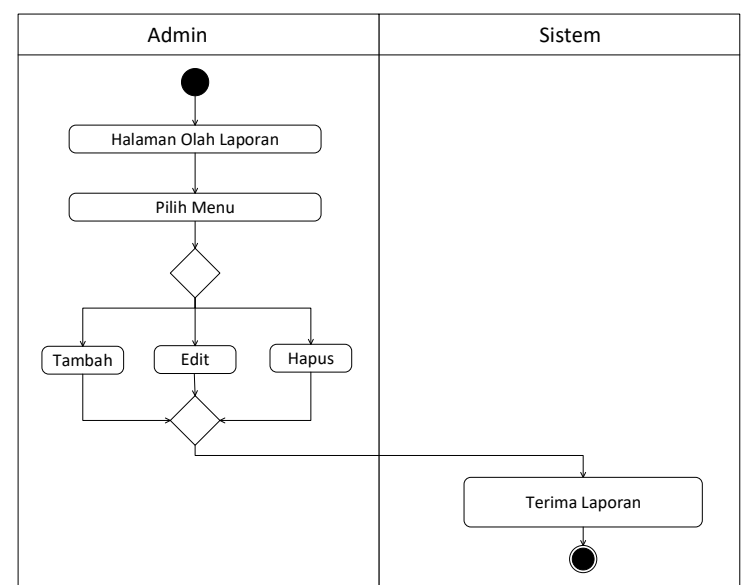

Gambar 8. Gambar activity diagram SMS

Dapat diketahui dari Gambar 8 bahwa:

1. User membuat laporan

2. User dapat menambah laporan, edit data laporan dan menghapus data laporan

3. Laporan yang telah di selesaikan dilaporkan ke pimpinan

\section{c. Sequence Diagram}

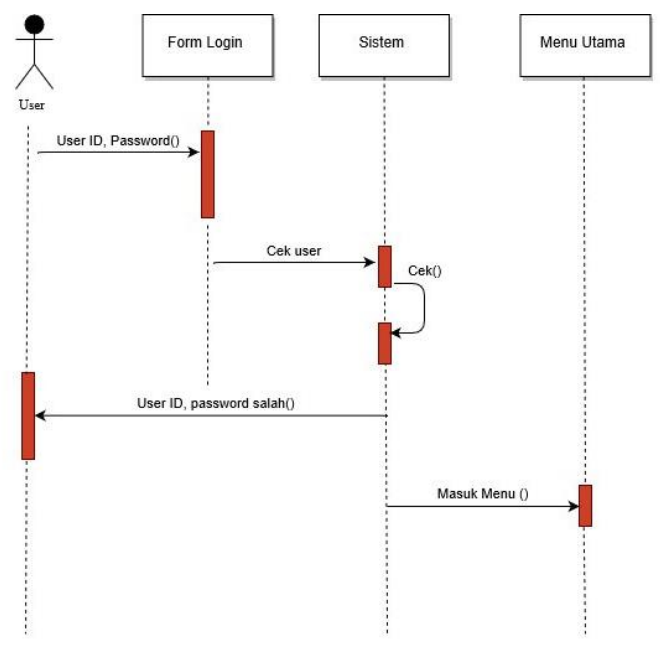

Gambar 9. Sequence diagram login

Alur Sequence pada login (Gambar 9) adalah user masuk ke form login, kemudian setelah form login terisi, sistem akan mengecek kebenaran isi form login, bila tidak sesuai maka sistem akan memberikan konfirmasi password salah, akan tetapi bila form tersebut sesuai dengan data yang ada di sistem maka sistem memperbolehkan user untuk masuk ke menu.

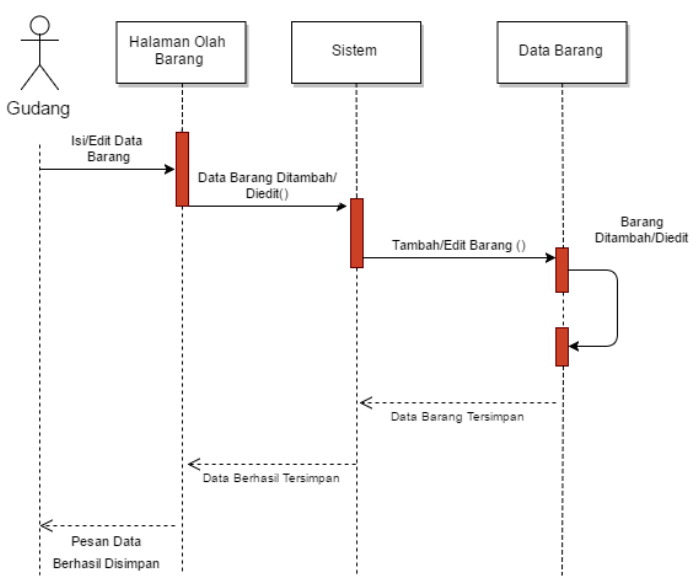

Gambar 10. Sequence diagram input data / edit barang

Pada user gudang, setelah user masuk kemenu dan ingin menginput barang, user pilih menu barang, kemudian di halaman tersebut user bisa menginput data barang dan juga dapat menghapus serta mengubah data barang. Setelah data tersebut diolah sesuai keinginan user maka sistem akan menyimpan ke data transaksi (Gambar 10). 


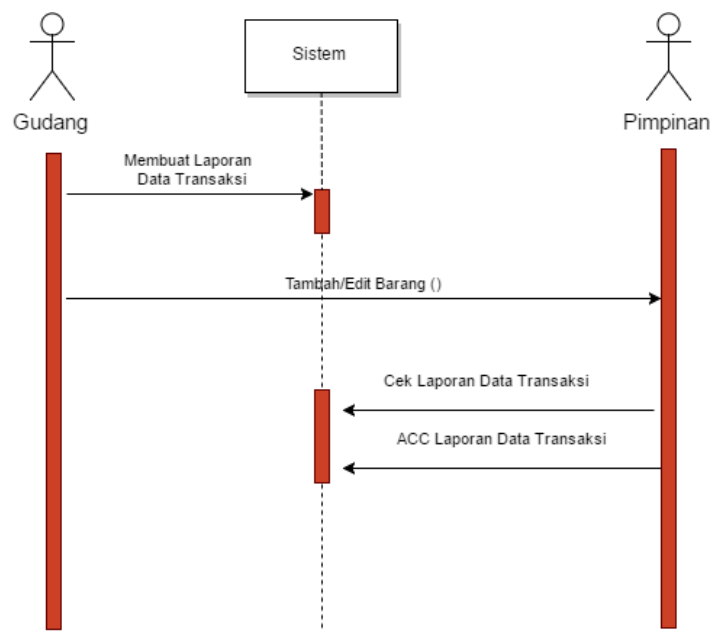

Gambar 11. Sequence diagram laporan cek data barang

Pada user karyawan gudang untuk pengecekan barang di sistem (Gambar 11), user gudang memilih halaman pengecekan barang, kemudian pilih data barang yang ingin dicek, kemudian sistem akan mencocokkan kode barang dengan data barang. Bila data barang ditemukan maka sistem akan menampilkan konfirmasi pada halaman cek data barang. Apabila data tidak ditemukan di data barang.

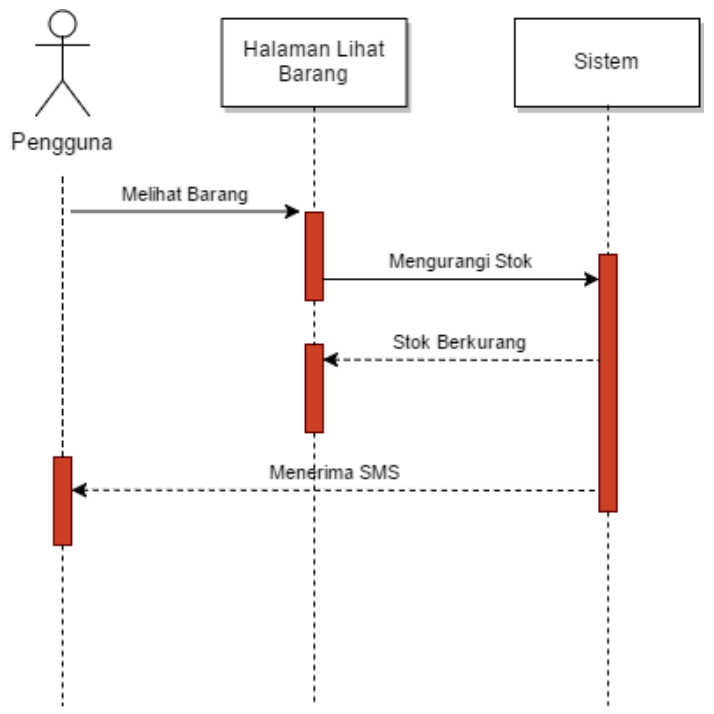

Gambar 12. Sequence diagram SMS
Pada sequence diagram SMS (Gambar 12), pengguna mengurangi stok barang pada halaman lihat barang. Stok barang berkurang dan ditampilkan langsung di halaman lihat barang. Pengguna menerima SMS ketika stok barang dikurangi.

\subsection{Implementasi}

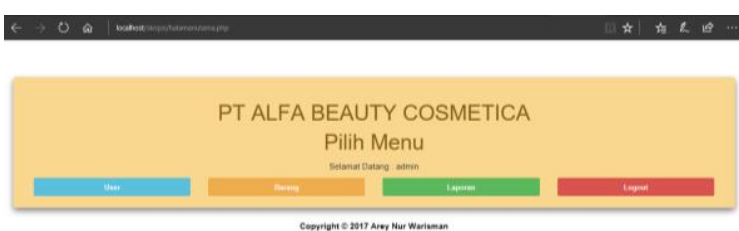

Gambar 13. Halaman utama aplikasi

Gambar 13 merupakan halaman menu utama admin, admin mempunyai semua hak akses yaitu menu user, barang, dan laporan.

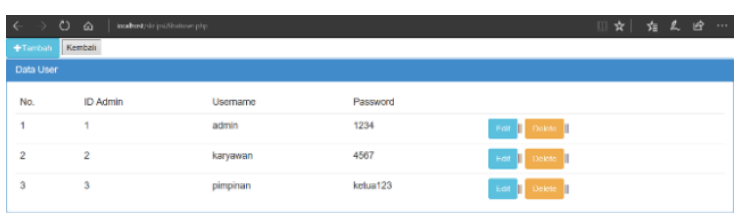

Gambar 14. Halaman data user

Gambar 14 merupakan Halaman Data User hanya bisa diakses oleh admin. Pada halaman ini, admin dapat menambah, mengubah dan menghapus user. 


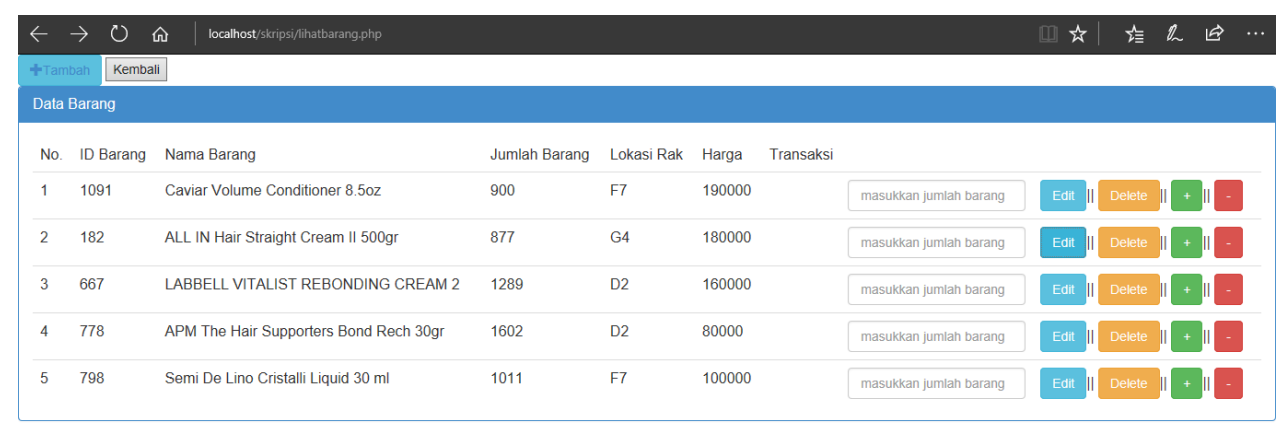

Gambar 15. Halaman data barang

Gambar 15 merupakan halaman data barang, dimana pada halaman ini ditampilkan seluruh data barang. Pengguna yang bisa mengakses halaman data barang adalah pengguna yang mempunyai hak akses "admin" dan "pegawai". Admin dan pegawai dapat menambah, mengubah, menghapus dan melakukan transaksi barang.

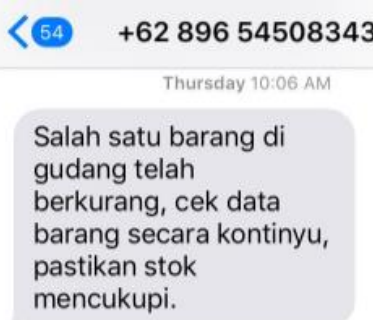

Gambar 16. Tampilan SMS
Gambar 16 merupakan tampilan SMS yang akan diterima oleh pengguna bila stok barang yang ada di gudang telah berkurang. Dengan adanya SMS Gateway maka pimpinan dapat mengetahui proses supply chain sehingga dapat menghindari terjadinya terhentinya proses kerja perusahaan dikarenakan stok terhadap inventory yang kosong.

Tabel 7. Pengujian black box.

\begin{tabular}{|c|c|c|c|c|c|}
\hline No & $\begin{array}{l}\text { Proses yang } \\
\text { diuji }\end{array}$ & Cara Pengujian & Sifat & Hasil yang diharapkan & $\begin{array}{c}\text { Hasil yang } \\
\text { didapat }\end{array}$ \\
\hline \multirow[t]{5}{*}{1} & \multirow[t]{5}{*}{ Login } & $\begin{array}{l}\text { Memasukkan } \\
\text { Username \& } \\
\text { Password } \\
\end{array}$ & Normal & $\begin{array}{l}\text { Sistem menampilkan versi } \\
\text { aplikasi untuk admin }\end{array}$ & Sesuai \\
\hline & & $\begin{array}{c}\text { Memasukkan } \\
\text { Username \& } \\
\text { Password } \\
\end{array}$ & Normal & $\begin{array}{l}\text { Sistem menampilkan versi } \\
\text { aplikasi untuk karyawan }\end{array}$ & Sesuai \\
\hline & & $\begin{array}{c}\text { Memasukkan } \\
\text { Username \& } \\
\text { Password } \\
\end{array}$ & Normal & $\begin{array}{l}\text { Sistem menampilkan versi } \\
\text { aplikasi untuk pimpinan }\end{array}$ & Sesuai \\
\hline & & $\begin{array}{l}\text { Salah memasukkan } \\
\text { username \& } \\
\text { password } \\
\end{array}$ & $\begin{array}{l}\text { Tidak } \\
\text { Normal }\end{array}$ & $\begin{array}{l}\text { Sistem menyatakan bahwa } \\
\text { login gagal }\end{array}$ & Sesuai \\
\hline & & $\begin{array}{l}\text { Memilih halaman } \\
\text { lupa password }\end{array}$ & $\begin{array}{c}\text { Tidak } \\
\text { Normal } \\
\end{array}$ & $\begin{array}{c}\text { Sistem melakukan } \\
\text { penyimpanan password baru }\end{array}$ & Sesuai \\
\hline \multirow[t]{2}{*}{2} & \multirow[t]{2}{*}{$\begin{array}{l}\text { Menambah } \\
\text { user }\end{array}$} & $\begin{array}{l}\text { Mengisi semua data } \\
\text { yang diperlukan }\end{array}$ & Normal & $\begin{array}{c}\text { Sistem menampilkan rincian } \\
\text { data yang terisi }\end{array}$ & Sesuai \\
\hline & & $\begin{array}{l}\text { Tidak mengisi semua } \\
\text { data }\end{array}$ & $\begin{array}{l}\text { Tidak } \\
\text { Normal }\end{array}$ & $\begin{array}{l}\text { Sistem meminta pengguna } \\
\text { untuk mengisi kekurangan } \\
\text { data }\end{array}$ & Sesuai \\
\hline 3 & $\begin{array}{l}\text { Mengubah data } \\
\text { user }\end{array}$ & $\begin{array}{l}\text { Masuk ke activity } \\
\text { edit data } \text { user }\end{array}$ & Normal & $\begin{array}{c}\text { Menampilkan data } \text { user yang } \\
\text { akan diubah sesuai } \\
\text { berdasarkan id } \text { user }\end{array}$ & Sesuai \\
\hline
\end{tabular}




\begin{tabular}{|c|c|c|c|c|c|}
\hline & & & $\begin{array}{l}\text { Tidak } \\
\text { Normal }\end{array}$ & Menampilkan pesan gagal & Sesuai \\
\hline \multirow[t]{3}{*}{4} & \multirow[t]{3}{*}{$\begin{array}{l}\text { Menambah } \\
\text { barang }\end{array}$} & $\begin{array}{l}\text { Mengisi semua data } \\
\text { barang yang } \\
\text { diperlukan } \\
\end{array}$ & Normal & $\begin{array}{c}\text { Sistem menampilkan rincian } \\
\text { data yang terisi }\end{array}$ & Sesuai \\
\hline & & $\begin{array}{l}\text { Tidak mengisi semua } \\
\text { data barang }\end{array}$ & $\begin{array}{l}\text { Tidak } \\
\text { Normal }\end{array}$ & $\begin{array}{c}\text { Sistem meminta pengguna } \\
\text { untuk mengisi kekurangan } \\
\text { data }\end{array}$ & Sesuai \\
\hline & & $\begin{array}{c}\text { Sengaja menghapus } \\
\text { semua data }\end{array}$ & $\begin{array}{c}\text { Tidak } \\
\text { Normal }\end{array}$ & & Sesuai \\
\hline \multirow[t]{2}{*}{5} & \multirow[t]{2}{*}{$\begin{array}{l}\text { Transaksi } \\
\text { barang }\end{array}$} & \multirow[t]{2}{*}{$\begin{array}{l}\text { Menginput jumlah } \\
\text { barang yang akan } \\
\text { ditransaksikan }\end{array}$} & Normal & $\begin{array}{c}\text { Jumlah barang } \\
\text { bertambah/berkurang sesuai } \\
\text { dengan jumlah angka } \\
\text { transaksi }\end{array}$ & Sesuai \\
\hline & & & $\begin{array}{l}\text { Tidak } \\
\text { Normal }\end{array}$ & $\begin{array}{c}\text { Jumlah barang tidak } \\
\text { bertambah/berkurang sesuai } \\
\text { dengan jumlah angka } \\
\text { transaksi }\end{array}$ & Sesuai \\
\hline \multirow[t]{2}{*}{6} & \multirow[t]{2}{*}{$\begin{array}{l}\text { Mengubah data } \\
\text { barang }\end{array}$} & \multirow[t]{2}{*}{$\begin{array}{l}\text { Masuk ke activity } \\
\text { edit data barang }\end{array}$} & Normal & $\begin{array}{l}\text { Menampilkan data barang } \\
\text { yang akan diubah sesuai } \\
\text { berdasarkan id barang }\end{array}$ & Sesuai \\
\hline & & & $\begin{array}{c}\text { Tidak } \\
\text { Normal }\end{array}$ & Menampilkan pesan gagal & Sesuai \\
\hline \multirow[t]{3}{*}{7} & \multirow{3}{*}{$\begin{array}{l}\text { Melihat } \\
\text { laporan data } \\
\text { barang }\end{array}$} & \multirow[t]{2}{*}{$\begin{array}{l}\text { Masuk ke activity } \\
\text { laporan data barang }\end{array}$} & Normal & $\begin{array}{l}\text { Menampilkan semua data } \\
\text { laporan }\end{array}$ & Sesuai \\
\hline & & & $\begin{array}{c}\text { Tidak } \\
\text { Normal }\end{array}$ & $\begin{array}{l}\text { Data laporan data barang } \\
\text { tidak muncul }\end{array}$ & Sesuai \\
\hline & & $\begin{array}{c}\text { Pengguna masuk } \\
\text { activity download } \\
\text { laporan }\end{array}$ & Normal & $\begin{array}{c}\text { Data laporan tersimpan } \\
\text { dengan bentuk .xlsx }\end{array}$ & Sesuai \\
\hline \multirow[t]{2}{*}{8} & \multirow[t]{2}{*}{$\begin{array}{c}\text { Melihat } \\
\text { laporan barang }\end{array}$} & \multirow[t]{2}{*}{$\begin{array}{c}\text { Jumlah barang } \\
\text { kurang dari } 50 \text { buah }\end{array}$} & Normal & $\begin{array}{c}\text { SMS terkirim ke nomor } \\
\text { telepon penerima SMS }\end{array}$ & $\begin{array}{l}\text { Tidak } \\
\text { Sesuai }\end{array}$ \\
\hline & & & $\begin{array}{c}\text { Tidak } \\
\text { normal }\end{array}$ & $\begin{array}{c}\text { SMS tidak terkirim ke nomor } \\
\text { telepon penerima SMS }\end{array}$ & \\
\hline
\end{tabular}

\subsection{Pembahasan}

Sistem Pengingat Pada Gudang PT Alfa Beauty Cosmetica dibuat dengan menggunakan bahasa pemrograman PHP dan database MySQL, dimana notifikasi dikirimkan melalui SMS [4][5][6][7]. Hasil ini selaras dengan penelitian Sihotang dan Jumeilah [8] bahwa GAMMU dapat diterapkan pada client-server atau berbasis web.

\section{PENUTUP}

Kesimpulan dalam penelitian ini adalah:

1. Aplikasi ini bermanfaat untuk mempermudah pekerjaan karyawan PT. Alfa Beauty Cosmetica. Apabila stok di gudang berkurang, maka aplikasi ini akan memberikan informasi kepada karyawan gudang

2. Aplikasi ini berguna untuk karyawan karena tidak lagi menulis laporan secara manual. Pencatatan yang dilakukan telah terkomputerisasi, sehingga apabila ada perubahan data maka pengguna yang berkaitan akan diberikan informasi.

3. Aplikasi ini mempercepat pekerjaan karyawan dalam pelaporan jumlah barang. Karena apabila ada stok yang berkurang maka pihak gudang akan segera diberikan informasi mengenai hal tersebut.

\section{DAFTAR PUSTAKA}

[1] Y. Jumaryadi, "Customer Complaint Information Systems at National 
Standardization Agency of Indonesia," Int. J. Inf. Syst. Comput. Sci., vol. 3, no. 2, pp. 43-49, 2019.

[2] E. K. Suni and W. Ridwan, "Analisis Dan Perancangan Data Warehouse Untuk Mendukung Keputusan Redaksi Televisi Menggunakan Metode Nine-Step Kimball," J. Tek. Inform., vol. 11, no. 2, pp. 197-206, 2018.

[3] R. S. Pressman and B. Maxim, Software Engineering: A Practitioner's Approach, 8th Editio. New York: McGraw-Hill Education, 2014.

[4] M. R. Meta, I. E. Putra, and A. Urfa, "Aplikasi Penerimaan Mahasiswa Baru Online Dengan Sms Gateway di STMIK Indonesia Padang," J. RESTI (Rekayasa Sist. dan Teknol. Informasi), vol. 2, no. 3, pp. 716-721, 2018.

[5] T. Susilowati, M. Ihsan Dacholfany, S. Aminin, A. Ikhwan, B. Mohd. Nasir, M. Huda, A. Prasetyo, A. Maseleno, F. Satria, S. Hartati, and Wulandari, "Getting parents involved in child's school: using attendance application system based on SMS gateway," Int. J. Eng. Technol., vol. 7, no. 2.27, p. 167, 2018.

[6] J. S. Ratu, S. Juanita, and Windarto, "Otomasi Sistem Rumah Anti Banjir dengan Notifikasi SMS," J. Format, vol. 6, no. 2, pp. 11-24, 2017.

[7] R. Yusuf and Y. Susanto, "Pemanfaatan SMS Gateway untuk Absensi Sekolah Siswa," Semin. Nas. Pengaplikasian Telemat. SINAPTIKA 2010, pp. 1-4, 2010.

[8] F. P. Sihotang and F. S. Jumeilah, "Pengembangan SMS Gateway Layanan Informasi Akademik di STMIK GI MDP," J. RESTI (Rekayasa Sist. dan Teknol. Informasi), vol. 1, no. 1, p. 58, 2017.

\section{Hak Cipta}

Semua naskah yang tidak diterbitkan, dapat dikirimkan di tempat lain. Penulis bertanggung jawab atas ijin publikasi atau pengakuan gambar, tabel dan bilangan dalam naskah yang dikirimkannya. Naskah bukanlah naskah jiplakan dan tidak melanggar hak-hak lain dari pihak ketiga. Penulis setuju bahwa keputusan untuk menerbitkan atau tidak menerbitkan naskah dalam jurnal yang dikirimkan penulis, adalah sepenuhnya hak Pengelola. Sebelum penerimaan terakhir naskah, penulis diharuskan menegaskan secara tertulis, bahwa tulisan yang dikirimkan merupakan hak cipta penulis dan menugaskan hak cipta ini pada pengelola. 